\title{
PENINGKATAN HASIL BELAJAR MATEMATIKA SISWA KELAS VII SMP NEGERI 3 MAWASANGKA PADA MATERI BENTUK ALJABAR MELALUI MODEL PEMBELAJARAN KOOPERATIF TIPE NUMBERED HEAD TOGHETER
}

\author{
Nur Andriani ${ }^{1)}$, Hafiludin Samparadja ${ }^{2)}$,Kadir Tiya ${ }^{3)}$ \\ ${ }^{1)}$ Alumni Jurusan Pendidikan Matematika, ${ }^{2,3)}$ Dosen Jurusan Pendidikan Matematika \\ FKIP Universitas Halu Oleo: email: andrianinur045@gmail.com; \\ hafiludin79@yahoo.com; kadir.tiya@yahoo.com
}

\begin{abstract}
Abstrak
Nur Andriani, (2018), telah melakukan penelitian dengan judul "Meningkatkan Hasil Belajar Matematika Siswa Kelas VII ${ }_{\mathrm{A}}$ SMP Negeri 3 Mawasangka pada Materi Bentuk Aljabar Melalui Model Pembelajaran Kooperatif Tipe Numbered Heads Together". Penelitian ini bertujuan untuk meningkatkan hasil belajar matematika siswa kelas VII ${ }_{\mathrm{A}}$ SMP Negeri 3 Mawasangka pada materi bentuk aljabar melalui model pembelajaran kooperatif tipe NHT. Penelitian ini dilaksanakan pada semester ganjil tahun ajaran 2017/2018 di kelas VII $_{\mathrm{A}}$ SMP Negeri 3 Mawasangka dengan jumlah siswa 25 orang. Hasil penelitian menunjukkan bahwa: Hasil belajar Matematika siswa kelas VII $_{\mathrm{A}}$ SMP Negeri 3 Mawasangka dapat ditingkatkan melalui model pembelajaran Kooperatif tipe NHT. Peningkatan dapat dilihat dari banyaknya siswa yang tuntas pada hasil evaluasi dari siklus I sampai siklus III, secara berturut-turut yaitu: $0 \%, 44 \%$, dan $80 \%$. Adapun persentase peningkatan skor ratarata hasil belajar siswa dari siklus I ke siklus II yaitu 25,22, sedangkan siklus II ke siklus III yaitu sebesar $12,4 \%$.
\end{abstract}

Kata Kunci: model pembelajaran kooperatif, proses belajar-mengajar, hasil belajar

\section{INCREASED MATH STUDENT LEARNING OUTCOMES CLASS VII SMP NEGERI 3 MAWASANGKA ON ALGEBAR FORM MATERIAL THROUGH COOPERATIVE LEARNING MODEL TYPE NUMBERED HEAD TOGHETER}

\begin{abstract}
Nur Andriani, (2018), has conducted a research entitled "Improving the Results of Student Belt of Class VII $_{\mathrm{A}}$ SMP Negeri 3 Mawasangka on Algebraic Form Matter Through Cooperative Learning Model Numbered Heads Together". This study aims to improve the results of mathematics teaching bell student of class VII $_{\mathrm{A}}$ SMP Negeri 3 Mawasangka on algebraic material form through cooperative learning model type NHT. This study was conducted in the odd semester know n 2017/2018 teachings in class $\mathrm{VII}_{\mathrm{A}}$ SMP Negeri 3 Mawasangka with the number of students 25 people. The results showed that: The results of the teaching bell Math class students $\mathrm{VII}_{\mathrm{A}}$ SMP Negeri 3 Mawasangka can be improved through cooperative learning model type NHT. Strengthening can be seen from the number of students who pass the evaluation results from the first cycle to the third cycle, respectively: $0 \%, 44 \%$ and $80 \%$. The percentage increase in the average score of student learning outcomes from cycle I to cycle II is 25.22 , while cycle II to cycle III that is equal to $12.4 \%$.
\end{abstract}

Keywords: cooperative learning model, teaching-learning process, learning outcomes. 


\section{NJurnal Penelitian Pendididikan Matematika Volume 7 No.2 Mei 2019}

\section{Pendahuluan}

Pendidikan sebagai bagian integral kehidupan masyarakat di era global harus dapat memberi dan memfasilitasi tumbuh dan berkembangnya keterampilan intelektual, sosial dan personal. Pendidikan harus mampu menumbuhkan berbagai kompetensi peserta didik. Keterampilan intelektual, sosial, dan personal dibangun tidak hanya dengan landasan rasio dan logika saja, tetapi juga inspirasi, kreativitas, moral, intuisi (emosi), dan spiritual. Sekolah sebagai institusi pendidikan dan miniatur masyarakat perlu mengembangkan pembelajaran sesuai tuntutan kebutuhan era global.

Sekolah adalah tempat dimana seseorang memperoleh pendidikan secara lebih terstruktur, sistematis, terencana, serta berkelanjutan. Di sekolahlah sumber daya manusia (SDM) dibentuk dan dididik secara lebih terarah agar memiliki bekal yang cukup untuk bersaing dalam dinamika zaman yang semakin maju dan berkembang dengan pesat ini. Sumber daya manusia yang berkualitas sangat diperlukan untuk mengimbangi perkembangan ini. Kualitas sumber daya manusia sangat ditandai dengan kualitas serta mutu pendidikannya.

Matematika merupakan ilmu universal yang berguna bagi kehidupan manusia dan juga mendasari perkembangan teknologi modern, serta mempunyai peran penting dalam berbagai disiplin dan memajukan daya pikir manusia. Perkembangan pesat di bidang teknologi informasi dan komunikasi dewasa ini dilandasi oleh perkembangan matematika di bidang teori bilangan, aljabar, analisis, teori peluang, dan matematika diskrit. Untuk menguasai dan mencipta teknologi di masa depan, diperlukan penguasaan dan pemahaman atas matematika yang kuat sejak dini (As'ari, Tohir, Valentino, Imron, dan Taufiq, 2016: 12).

Rendahnya hasil belajar siswa merupakan salah satu permasalahan umum yang terjadi dalam dunia pendidikan. Kaitannya dengan mata pelajaran, bidang studi matematika dianggap sebagai mata pelajaran yang kurang menarik, sukar dan membosankan sehingga hasil belajar matematika siswa cenderung rendah. Hal ini terlihat pula pada siswa kelas VII SMP Negeri 3 Mawasangka, masih banyak siswa yang mengalami kesulitan dalam memahami mata pelajaran matematika khususnya pada materi bentuk aljabar.

Berdasarkan wawancara peneliti dengan guru pengampu mata pelajaran matematika, diperoleh fakta bahwa hasil ulangan harian yang diperoleh siswa pada materi bentuk aljabar pada semester ganjil tahun ajaran 2016/2017 untuk kelas VII belum mencapai kriteria ketuntasan minimal (KKM) yang ditetapkan sekolah yaitu 75. Padahal bentuk aljabar merupakan ilmu dasar dalam matematika yang sangat penting peranannya dalam kehidupan sehari-hari. Faktor ini dipengaruhi oleh cara mengajar guru yang masih menggunakan pendekatan tradisional, yaitu duduk, dengar, catat dan hafal. Pembelajaran jadi membosankan, tidak menarik dan hasilnya tidak memuaskan. Waktu untuk mengerjakan soalpun terasa lebih lama, sehingga tidak semua soal dapat terjawab dengan cepat dan benar.

Berdasarkan uraian di atas, maka peneliti menawarkan suatu tindakan alternatif untuk mengatasi masalah yang ada berupa penerapan model pembelajaran lain yang lebih mengutamakan keaktifan siswa dan memberi kesempatan siswa untuk mengembangkan potensinya secara maksimal. Model pembelajaran yang dimaksud adalah model pembelajaran kooperatif.

Salah satu model pembelajaran yang menjadikan peserta didik mandiri dalam belajar dan mempunyai kemampuan bersosialisasi dan memiliki jiwa kepemimpinan adalah model pembelajaran kooperatif (cooperative learning). Suprijono (2009) menyatakan bahwa pembelajaran kooperatif dikembangkan untuk mencapai hasil belajar berupa prestasi akademik, toleransi, menerima keragaman, dan pengembangan keterampilan sosial. Salah satu jenis model pembelajaran kooperatif adalah tipe Numbered Heads Together (NHT) yang merupakan sebuah variasi diskusi kelompok dan dapat menjamin keterlibatan total semua peserta didik. Secara singkat, langkah-langkah dalam proses pembelajaran kooperatif tipe NHT yaitu siswa aktif bekerja dalam kelompok. Mereka bertanggung jawab penuh terhadap soal yang diberikan. Misalnya siswa yang bernomor urut 2 dalam kelompoknya mempertanggungjawabkan soal nomor urut 2 dan seterusnya. Walaupun pada soal presentase mereka bisa ditunjuk untuk mengerjakan nomor lain. Pembelajaran kooperatif tipe NHT juga dinilai lebih memudahkan siswa berinteraksi dengan teman- 
teman dalam kelas dibandingkan dengan model pembelajaran yang selama ini diterapkan oleh guru. Pada model pembelajaran kooperatif tipe NHT siswa perlu berkomunikasi satu sama lain, sedangkan pada model pembelajaran langsung siswa duduk berhadap-hadapan dengan guru dan terus memperhatikan gurunya.

Berdasarkan uraian di atas, mendorong peneliti untuk mengadakan penelitian dalam bentuk penelitian tindakan kelas dengan judul,"Peningkatan Hasil Belajar Matematika Siswa kelas $\mathrm{VII}_{\mathrm{A}}$ SMP Negeri 3 Mawasangka pada Materi Bentuk Aljabar melalui Model Pembelajaran Kooperatif Tipe Numbered Heads Together".

Berdasarkan latar belakang, maka masalah dalam penelitian ini dirumuskan sebagai berikut: Bagaimana gambaran aktivitas mengajar guru dalam proses pembelajaran matematika kelas $\mathrm{VII}_{\mathrm{A}}$ SMP Negeri 3 Mawasangka pada materi bentuk aljabar dengan menggunakan Model Pembelajaran Kooperatif Tipe NHT? Bagaimana gambaran aktivitas belajar siswa dalam proses pembelaran matematika kelas $\mathrm{VII}_{\mathrm{A}}$ SMP Negeri 3 Mawasangka pada materi bentuk aljabar dengan menggunakan Model Pembelajaran Kooperatif Tipe NHT? Apakah hasil belajar matematika siswa kelas VII $_{\mathrm{A}}$ SMP Negeri 3 Mawasangka pada materi bentuk aljabar dapat ditingkatkan melalui Model Pembelajaran Kooperatif Tipe NHT?".

Sesuai dengan rumusan masalah yang telah dikemukakan di atas, maka tujuan penelitian ini adalah untuk: Memperoleh gambaran aktivitas mengajar guru dalam proses pembelajaran matematika kelas $\mathrm{VII}_{\mathrm{A}} \mathrm{SMP}$ Negeri 3 Mawasangka pada materi bentuk aljabar melalui Model Pembelajaran Kooperatif Tipe NHT; Memperoleh gambaran aktivitas belajar siswa dalam proses pembelaran matematika kelas $\mathrm{VII}_{\mathrm{A}}$ SMP Negeri 3 Mawasangka pada materi bentuk aljabar melalui Model Pembelajaran Kooperatif Tipe NHT; Meningkatkan hasil belajar matematika siswa kelas VII $_{\mathrm{A}}$ SMP Negeri 3 Mawasangka pada materi bentuk aljabar melalui Model Pembelajaran Kooperatif Tipe NHT.

Pembelajaran (proses belajar mengajar) adalah upaya secara sistematis yang dilakukan guru untuk mewujudkan proses pembelajaran berjalan secara efektif dan efisien yang dimulai dari perencanaan, pelaksanaan dan evaluasi. Kemampuan mengelola pembelajaran merupakan syarat mutlak bagi guru agar terwujud kompetensi profesionalnya. Konsekuensinya, guru harus memiliki pemahaman yang utuh dan tepat terhadap konsepsi belajar dan mengajar (Aqib, 2015: 66).

Suherman (Jihad, 2008: 11) menyatakan bahwa pembelajaran merupakan suatu proses yang terdiri dari kombinasi dua aspek, yaitu: belajar tertuju kepada apa yang harus dilakukan oleh siswa, mengajar berorientasi pada apa yang harus dilakukan oleh guru sebagai pemberi pelajaran. Kedua aspek ini akan berkolaborasi secara terpadu menjadi suatu kegiatan pada saat terjadi interaksi antara guru dengan siswa, serta antara siswa dengan siswa di saat pembelajaran sedang berlangsung. Dengan kata lain, pembelajaran pada hakikatnya merupakan proses komunikasi antara peserta didik dengan pendidik serta antar peserta didik dalam rangka perubahan sikap. Komunikasi didefinisikan sebagai proses dimana partisipan/siswa menciptakan dan saling berbagi informasi satu sama lain guna mencapai pengertian timbal balik.

Pembelajaran adalah suatu situasi yang tercipta dari interaksi yang berlangsung antara berbagai faktor (multiple factor) ataupun komponen; guru, siswa (peserta didik), kurikulum, metode, sarana dan media serta komponen lainnya yang diperlukan. Sedangkan tujuan yang diharapkan dari suatu pembelajaran tiada lain berkisar pada analisis tentang bagaimana cara menghilangkan kesenjangan antara perilaku yang ada sekarang dengan perilaku yang diharapkan di masa yang akan datang setelah pembelajaran itu selesai dilaksanakan (Yasin, 2012: 3).

Usman (Jihad, 2008: 12) menyatakan pembelajaran adalah inti dari proses pendidikan secara keseluruhan dengan guru sebagai pemegang peranan utama. Pembelajaran merupakan suatu proses yang mengandung serangkaian perbuatan guru dan siswa atas dasar hubungan timbal balik yang berlangsung dalam situasi edukatif untuk mencapai tujuan tertentu.

Pembelajaran meliputi dua aspek, yaitu belajar dan mengajar. Belajar dan mengajar merupakan dua konsep yang tidak dapat dipisahkan satu sama lain. Untuk memperoleh pengertian yang obyektif tentang proses belajarmengajar matematika maka perlu lebih dahulu dikemukakan mengenai proses belajar mengajar itu sendiri, khususnya pengertian belajar dan mengajar secara umum. 


\section{NJurnal Penelitian Pendididikan Matematika Volume 7 No.2 Mei 2019}

Salah satu defenisi belajar yang dapat dikemukakan adalah apa yang ditulis oleh Smith (Yasin, 2012: 3) berikut:"Learning refers to changes in behavior, change which are attributible to a set of antecedent conditions categorized as experience and training rather than to processes such a maturation, growth, physiology, perseption, or motivation. In addition, the changes in performance, with we define as learning are relatively speaking, permanent rather than transtory; they persist for some time. If only a few minutes".

Ada dua kata kunci yang penting diperhatikan dalam defenisi di atas, yakni behavior (tingkah laku) yakni perubahan dalam tingkah laku dan performance (penampilan) dimana seorang peserta didik yang telah melewati suatu proses belajar dengan materi tertentu, akan mengalami perubahan dalam penampilannya baik secara lahiriah maupun secara kejiwaan. Dua istilah tersebut terkait dengan penampilan luar yang dapat diamati secara inderawi maupun kemungkinan isi di dalamnya secara psikologis. Kedua hal tersebut merupakan capaian dari kegiatan yang disebut belajar. Pengalaman belajar setidaknya akan membawa kepada perubahan tingkah laku dan perubahan penampilan dari subjek belajar yang bersangkutan. Oleh karenanya jika dalam diri seorang subjek belajar tidak terjadi dalam diri mereka perubahan dimaksud di atas, berarti belajar yang dilakukannya tidak berhasil atau paling tidak dianggap telah terjadi stagnasi.

Belajar merupakan perubahan tingkah laku. Seseorang dianggap belajar bila menunjukkan perubahan tingkah laku yang terjadi pada dirinya. Misalnya, seorang siswa belum bisa berhitung maka sekeras apapun gurunya berusaha mengajar bila siswa itu gagal mendemonstrasikan kemampuannya dalam berhitung, maka siswa itu belum bisa dikatakan belajar. Ia dikatakan telah belajar apabila ia menunjukkan suatu perubahan dalam tingkah laku (dari tidak bisa menjadi bisa berhitung). Dengan kata lain, belajar merupakan bentuk perubahan yang dialami siswa dalam hal kemampuannya untuk bertingkah laku dengan cara yang baru sebagai hasil interaksi antara stimulus dan respon (Ubaidah, 2016: 60-61).

$$
\text { Gagne (Suprijono, 2009: 2) }
$$

mendefinisikan belajar adalah perubahan disposisi atau kemampuan yang dicapai seseorang melalui aktivitas. Perubahan disposisi tersebut bukan diperoleh langsung dari proses pertumbuhan secara alamiah. Sedangkan, Sudjana (Jihad, 2008: 2) berpendapat bahwa belajar adalah suatu proses yang ditandai dengan adanya perubahan pada diri seseorang, perubahan sebagai hasil proses belajar dapat ditunjukkan dalam berbagai bentuk seperti perubahan pengetahuan, pemahaman, sikap dan tingkah laku, keterampilan, kecakapan, kebiasaan, serta perubahan aspek-aspek yang ada pada individu yang belajar.

Sudjana (Jihad, 2008: 2) berpendapat bahwa belajar adalah suatu proses yang ditandai dengan adanya perubahan pada diri seseorang, perubahan sebagai hasil proses belajar dapat ditunjukkan dalam berbagai bentuk seperti perubahan pengetahuan, pemahaman, sikap dan tingkah laku, keterampilan, kecakapan, kebiasaan, serta perubahan aspek-aspek yang ada pada individu yang belajar.

Berdasarkan beberapa pendapat di atas, dapat disimpulkan bahwa belajar adalah suatu proses perubahan tingkah laku individu yang mengakibatkan bertambahnya pengetahuan, keterampilan, dan nilai sikap yang diperoleh melalui interaksi individu dengan lingkungannya.

Terminologi belajar dan mengajar adalah dua peristiwa yang berbeda, akan tetapi antar keduanya terdapat hubungan yang erat dan saling mempengaruhi, seperti definisi belajar, mengajar juga diartikan dan ditafsirkan secara berbeda menurut zaman dan teori belajarmengajar yang dianut pada masa itu.

Istilah mengajar pada dasarnya merupakan suatu usaha untuk menciptakan kondisi atau sistem lingkungan yang mendukung dan memungkinkan untuk berlangsungnya proses belajar. Mengajar adalah sebagai kegiatan guru. Disamping itu, mengajar adalah menyampaikan pengetahuan pada anak didik. Menurut pengertian ini berarti tujuan belajar dari siswa itu hanya sekedar ingin mendapatkan atau menguasai pengetahuan. Sebagai konsekuensi pengertian semacam ini dapat membuat suatu kecendrungan anak menjadi pasif, karena hanya menerima informasi atau pengetahuan yang diberikan oleh gurunya. Guru menyampaikan pengetahuan, agar anak didik mengetahui tentang pengetahuan yang disampaikan oleh guru.

Pengertian secara luas, mengajar diartikan sebagai suatu aktivitas mengorganisasi atau mengatur lingkungan sebaik-baiknya dan menghubungkan dengan anak, sehingga terjadi 
proses belajar. Atau dikatakan, mengajar sebagai upaya menciptakan kondisi yang kondusif untuk berlangsungnya kegiatan belajar bagi para siswa. Kondisi itu diciptakan sedemikian rupa sehingga membantu perkembangan anak secara optimal baik jasmani maupun rohani, baik fisik maupun mental. Pengertian mengajar seperti ini memberikan petunjuk bahwa fungsi pokok dalam mengajar itu adalah menyediakan kondisi yang kondusif, sedang yang berperan aktif dan banyak melakukan kegiatan adalah siswanya, dalam upaya menemukan dan memecahkan masalah. Guru dalam hal ini adalah membimbing. Dalam membimbing dan menyediakan kondisi yang kondusif, itu sudang barang tentu guru tidak dapat mengabaikan faktor atau komponen-komponen yang lain dalam lingkungan proses belajar-mengajar, termasuk misalnya bagaimana dirinya sendiri, keadaan siswa, alat-alat peraga atau media, metode dan sumber-sumber belajar lainnya (Ichsan, 2016: 60).

S. Nasution (Aqib, 2015: 67) menyatakan bahwa mengajar merupakan suatu aktivitas mengorganisasi atau mengatur lingkungan sebaik-baiknya dan menghubungkannya dengan anak, sehingga terjadi belajar mengajar.

Berdasarkan beberapa pendapat para ahli di atas, dapat disimpulkan bahwa mengajar pada hakikatnya adalah proses menyampaikan pengetahuan kepada peserta didik sedemikian hingga tercapai tujuan belajarnya. Dalam proses tersebut, pengajar mencoba membantu, membimbing dan memotivasi peserta didik untuk mendapatkan pengetahuan, keterampilan dan sikap yang sesuai dengan tujuan belajarnya.

Hasil belajar adalah kemampuan yang diperoleh anak setelah melalui kegiatan belajar. Hasil belajar merupakan keluaran (outputs) dari suatu sistem pemrosesan masukan (input). Masukan dari sistem tersebut berupa bermacammacam informasi sedangkan keluarannya adalah perbuatan atau kinerja (performance) (Jihad, 2008: 14).

Sudijono (Sutrisno, 2016) mengungkapkan hasil belajar merupakan sebuah tindakan evaluasi yang dapat mengungkap aspek proses berpikir (cognitive domain) juga dapat mengungkap aspek kejiwaan lainnya, yaitu aspek nilai atau sikap (affective domain) dan aspek keterampilan (psychomotor domain) yang melekat pada diri setiap individu peserta didik. Ini artinya melalui hasil belajar dapat terungkap secara holistik penggambaran pencapaian siswa setelah melalui pembelajaran.

Menurut Juliah (Fitri, Helma, dan Syarifuddin, 2014: 19) hasil belajar adalah penguasaan yang dicapai oleh siswa setelah mengikuti proses pembelajaran. Hasil belajar yang diperoleh siswa dari suatu kegiatan yang mengakibatkan perubahan tingkah laku yang dinyatakan dengan skor/nilai yang diperoleh dari tes hasil belajar setelah proses pembelajaran. Pelaksanaan evaluasi dan penilaian hasil belajar penting dilakukan sebab hasil belajar sebagai ungkapan dan perwujudan hasil dari pelaksanaan pembelajaran.

Pembelajaran yang menggunakan model kooperatif dapat memiliki ciri-ciri sebagai berikut: (a) siswa bekerja dalam kelompok secara kooperatif untuk menuntaskan materi belajarnya, (b) kelompok dibentuk dari siswa yang memiliki kemampuan tinggi, sedang dan rendah, (c) bilamana mungkin, anggota kelompok berasal dari ras, budaya, suku, jenis kelamin berbeda-beda dan (d) penghargaan lebih berorientasi kelompok ketimbang individu. Lingkungan belajar untuk pembelajaran kooperatif dicirikan oleh proses demokrasi dan peran aktif siswa dalam menentukan apa yang harus dipelajari dan bagaimana mempelajarinya. Guru menerapkan struktur pembentukan kelompok dan mendefinisikan semua prosedur, namun siswa diberi kebebasan mengendalikan dari waktu ke waktu dalam kelompoknya (Ibrahim, dkk, 2002: 7).

Pembelajaran kooperatif tipe NHT merupakan salah satu tipe pembelajaran kooperatif yang menekankan pada struktur khusus yang dirancang untuk mempengaruhi pola interaksi siswa dan memiliki tujuan untuk meningkatkan penguasaan akademik. Trianto (Wardani, 2016: 40 - 41) menjelaskan bahwa NHT adalah tipe pembelajaran kooperatif yang dirancamg untuk mempengaruhi pola interaksi siswa dan sebagai alternatif terhadap struktur kelas tradisional. Maksudnya, siswa akan lebih banyak dilibatkan dalam menelaah materi yang tercakup dalam suatu pelajaran dan mengecek pemahaman mereka terhadap isi pelajaran tersebut.

Menurut Daryanto dan Rahardjo (Wardani, 2016: 41), aktivitas dalam model pembelajaran kooperatif tipe NHT mendorong 
siswa untuk berpikir dalam suatu tim dan berani tampil mandiri sehingga dalam pelaksanaannya guru berperan sebagai fasilitator. Fasilitator mengatur kelas sedemikian rupa sehingga ada ruang yang cukup bagi sekelompok siswa.

Model pembelajaran kooperatif tipe NHT atau kepala bernomor diperkenalkan oleh Kagan (Aqib, 2015: 18 - 19), dengan langkahlangkah sebagai berikut; Siswa dibagi dalam kelompok, setiap siswa dalam kelompok mendapat nomor; Guru memberikan tugas dan masing-masing kelompok mengerjakannya; Kelompok mendiskusikan jawaban yang benar dan memastikan tiap anggota kelompok dapat mengerjakannya/mengetahui jawabannya; Guru memanggil salah satu nomor siswa dengan nomor yang dipanggil melaporkan hasil kerja sama mereka; Tanggapan dari teman yang lain, kemudian guru menunjuk nomor yang lain; Kesimpulan.

Langkah-langkah tersebut kemudian dikembangkan lebih lanjut oleh Ibrahim (2000: 29), sebagai berikut:

Langkah 1. Persiapan

Dalam tahap ini guru mempersiapkan rancangan pelajaran dengan membuat Rencana Pelaksanaan Pembelajaran (RPP), Lembar Kerja Siswa (LKS) yang sesuai dengan model pembelajaran kooperatif tipe NHT.

Langkah 2. Pembentukan dan pengorganisasian kelompok

Dalam pembentukan kelompok disesuaikan dengan model pembelajaran kooperatif tipe NHT. Guru membagi para siswa menjadi beberapa kelompok yang beranggotakan 3-5 orang siswa. Guru memberi nomor kepada setiap siswa dalam kelompok dan nama kelompok yang berbeda. Kelompok yang dibentuk merupakan pencampuran yang ditinjau dari latar belakang sosial, ras, suku, jenis kelamin, dan kemampuan belajar. Selain itu, dalam pembentukan kelompok digunakan nilai tes awal (pree test) sebagai dasar dalam menentukan masing-masing kelompok.

Langkah 3. Tiap kelompok harus memiliki buku paket atau buku panduan

Dalam pembentukan kelompok, tiap kelompok harus memiliki buku paket atau buku panduan agar memudahkan siswa dalam menyelesaikan LKS atau masalah yang diberikan oleh guru.

Buku panduan dalam penelitian ini berupa bahan ajar yang telah disiapkan oleh guru, dimana buku panduan ini telah disusun berdasarkan standar kompetensi, kompetensi dasar, dan indikator pembelajaran dari materi yang diajarkan. Dengan adanya buku panduan ini, siswa diharapkan lebih mudah memahami dan menguasai materi yang diberikan.

Langkah 4. Penyajian informasi

Dalam tahap ini, guru menyajikan beberapa informasi terkait materi yang dipelajari, dimana materi yang dipelajari telah tertuang ke dalam bahan ajar dan LKS yang telah dibagikan kepada masing-masing kelompok. Setelah guru memaparkan materi, guru menyajikan masalah dalam bentuk LKS yang jumlah soalnya sama dengan jumlah setiap anggota kelompok.

Langkah 5. Setiap siswa mengerjakan masalah sesuai nomornya

Dalam tahap ini, setiap siswa wajib mengerjakan soal dam memecahkan masalah sesuai nomornya. Tahap ini merupakan tahap yang lebih menekankan pada tanggung jawab individual siswa dalam kelompok, sehingga setiap siswa diwajibkan untuk melaksanakan kewajiban dan tanggung jawabnya masingmasing.

Langkah 6. Diskusi kelompok untuk memecahkan masalah

Dalam kerja kelompok setiap siswa memberitahu dan menjelaskan kepada anggota kelompoknya mengenai hasil pemecahan masalah yang telah diperolehnya secara individu, kemudian terjadi diskusi kelompok dan kegiatan berpikir bersama untuk menggambarkan dan meyakinkan bahwa tiap orang mengetahui jawaban dari pertanyaan yang telah ada dalam LKS atau pertanyaan yang diberikan oleh guru.

Langkah 7. Memanggil nomor anggota atau pemberian jawaban

Dalam tahap ini, guru menyebut satu nomor dan para siswa dari tiap kelompok dengan nomor yang sama mengangkat tangan dan menyiapkan jawaban kepada siswa di kelas. Guru memanggil siswa secara acak sehingga tiap siswa harus siap untuk mempresentasikan hasil kerjanya, baik hasil kerja individu maupun hasil diskusi kelompok.

Langkah 8. Pemberian penghargaan

Dalam tahap ini, guru memberikan penghargaan berupa tepuk tangan, acungan jempol, ataupun pemberian bonus kepada siswa yang berhasil mempresentasikan hasil kerjanya 
dengan baik serta kepada kelompok yang jawabannya benar.

Langkah 9. Pemberian kuis

Guru memberikan kuis berupa beberapa soal serupa dengan masalah yang telah dikerjakan dalam LKS, dan setiap siswa wajib mengerjakan soal secara individu.

Ada beberapa manfaat model pembelajaran kooperatif tipe NHT terhadap siswa dengan hasil belajar rendah yang dikemukakan oleh Lundgren (Ibrahim, 2000: 18), yaitu antara lain: 1) Rasa harga diri menjadi lebih tinggi; 2) Memperbaiki kehadiran; 3) Penerimaan terhadap individu menjadi lebih besar; 4) Perilaku mengganggu menjadi lebih kecil; 5) Konflik antara anggota kelompok berkurang; 6) Pemahaman yang lebih mendalam; 7) Meningkatkan kebaikan budi, kepekaan, dan toleransi; 8) Hasil belajar lebih tinggi.

Sedangkan Suwarno (Viyanita, 2013: 13) mengemukakan bahwa NHT mempunyai kelebihan dan kekurangan. Kelebihannya adalah sebagai berikut: 1) Kemungkinan konstruksi pengetahuan akan menjadi lebih besar; 2) Setiap siswa, baik siswa yang pintar maupun siswa yang lemah memiliki kesempatan yang sama untuk mengerjakan soal sesuai tanggung jawabnya; 3) Terjadi interaksi antara siswa melalui diskusi kelompok untuk memperoleh kesimpulan tentang pemecahan masalah yang dihadapi. Sedangkan kekurangannya yaitu kemungkinan ada perasaan minder dari siswa yang lemah karena kurang percaya diri dengan hasil kerjanya secara individu.

\section{Metode}

Penelitian ini adalah Penelitian Tindakan Kelas (PTK). PTK memiliki karakteristik sebagai berikut: 1) mengkaji permasalahan situasional dan kontekstual, 2) adanya tindakan, 3) adanya evaluasi terhadap tindakan, 4) pengkajian terhadap tindakan, 5) adanya kerjasama, 6) adanya refleksi (Paizaluddin dan Ermalinda, 2012: 43). Penelitian Tindakan Kelas (PTK) dilakukan dengan diawali oleh suatu kajian terhadap masalah secara sistematis. Hasil kajian ini kemudian dijadikan dasar untuk mengatasi masalah tersebut. Dalam proses pelaksanaan rencana yang telah disusun, kemudian dilakukan suatu observasi dan evaluasi hasil pakai sebagai masukan untuk melakukan refleksi atas apa yang terjadi pada tahapan pelaksanaan. Hasil dari proses refleksi ini kemudian melandasi upaya perbaikan dan penyempurnaan rencana tindakan berikutnya. Tahapan-tahapan di atas dilakukan berulang-ulang dan berkesinambungan sampai pada suatu standar kualitas keberhasilan tertentu dapat tercapai.

Penelitian ini dilaksanakan di SMP Negeri 3 Mawasangka pada semester ganjil tahun pelajaran 2017/2018, yaitu mulai tanggal 8 November sampai 30 November 2017, yang dilaksanakan selama tiga siklus yang setiap siklus terdiri dari dua kali pertemuan.

Subjek dalam penelitian ini adalah siswa kelas $\mathrm{VII}_{\mathrm{A}}$ SMP Negeri 3 Mawasangka yang berjumlah 25 orang yang terdiri dari 9 orang laki-laki dan 16 orang perempuan.

Faktor yang diteliti: 1) Faktor siswa: aktivitas belajar mereka selama proses pembelajaran (belajar kelompok, diskusi, presentasi, tugas-tugas) dan hasil belajar mereka setelah melalui model pembelajaran kooperatif tipe NHT dalam bentuk nilai; 2) Faktor guru: berupa aktivitas yang dilakukan selama proses pembelajaran dengan memperhatikan bagaimana persiapan materi, kesesuaian materi, kesesuaian media dan metode pembelajaran yang digunakan di kelas dengan model pembelajaran kooperatif tipe NHT; 3) Faktor sumber pelajaran: mengamati proses pelaksanaan pembelajaran dalam rangka menigkatkan hasil belajar matematika siswa melalui model pembelajaran kooperatif tipe NHT dengan Rencana Pelaksanaan Pembelajaran (RPP) yang telah dipersiapkan guru.

Prosedur penelitian tindakan kelas ini dilaksanakan terdiri dari 3 siklus, dengan tiap siklus dilaksanakan sesuai dengan perubahan yang ingin dicapai pada faktor-faktor yang diselidiki. Untuk dapat mengetahui hasil belajar siswa sebelum pelaksanaan tindakan, terlebih dahulu diberikan tes awal untuk mengetahui kemampuan awal siswa dan juga digunakan sebagai patokan dalam pengolahan nilai peningkatan hasil belajar.

\section{Hasil}

Sebelum melakukan tindakan dalam penelitian, peneliti melakukan observasi awal dan wawancara singkat dengan guru matematika kelas VII SMP Negeri 3 Mawasangka. Hasil observasi menunjukkan bahwa hasil belajar matematika siswa khususnya kelas VII masih 


\section{NJurnal Penelitian Pendididikan Matematika Volume 7 No.2 Mei 2019}

tergolong rendah dan model pembelajaran yang digunakan dalam pembelajaran adalah model pembelajaran yang konvensional. Berdasarkan hasil wawancara tersebut, diputuskan untuk menerapkan model pembelajaran kooperatif tipe NHT dalam mengajarkan materi bentuk aljabar di kelas $\mathrm{VII}_{\mathrm{A}}$.

Pada tanggal 8 November 2017 diadakan tes awal pada siswa kelas $\mathrm{VII}_{\mathrm{A}}$ untuk mengetahui kemampuan awal siswa. Nilai tes awal dijadikan acuan untuk mengetahui peningkatan hasil belajar matematika siswa kelas VII $_{\mathrm{A}}$ SMP Negeri 3 Mawasangka setelah diterapkan model pembelajaran kooperatif tipe NHT.

Soal-soal tes awal berupa materi yang telah selesai diajarkan yaitu materi himpunan yang merupakan materi sebelum materi bentuk aljabar. Dari tes awal tersebut, terlihat bahwa tidak ada siswa yang tuntas atau memperoleh nilai lebih dari atau sama dengan 75 (semua siswa memperoleh nilai di bawah nilai KKM) . Hal ini memberikan gambaran bahwa hasil belajar matematika siswa masih tergolong rendah.

Siklus I, setelah ditetapkan untuk menerapkan model pembelajaran kooperatif tipe NHT dalam mengajar matematika materi bentuk aljabar, maka kegiatan selanjutnya adalah menyiapkan beberapa hal yang diperlukan pada saat pelaksanaan tindakan. Setelah berkonsultasi dengan guru mata pelajaran matematika kelas VIIA SMP Negeri 3 Mawasangka, peneliti melakukan hal-hal sebagai berikut : membuat skenario pembelajaran untuk tindakan siklus I, membuat lembaran observasi terhadap guru dan siswa selama proses pembelajaran di kelas, membuat LKS, membuat alat evaluasi (tes hasil belajar), elaksanaan Tindakan

Pada tahap pelaksaan tindakan siklus I, kegiatan pembelajaran dengan model pembelajaran kooperatif tipe NHT dilaksanakan dengan skenario yang telah dipersiapkan. Dalam proses pembelajaran, siswa dibagi dalam 5 kelompok dengan nomor yang berbeda untuk setiap siswa dalam kelompoknya dan setiap kelompok beranggotakan 5 orang siswa. Selanjutnya setiap kelompok dibagikan LKS untuk didiskusikan bersama anggota kelompoknya, guru memberikan bimbingan kepada siswa dalam kelompok terutama kelompok yang mengalami kesulitan dalam menyelesaikan soal-soal dalam LKS. Kegiatan selanjutnya adalah siswa diminta mempresentasikan hasil kerja kelompoknya di depan kelas untuk siswa yang nomornya disebut dan siswa di kelompok lain memperhatikan dan membandingkan dengan pekerjaannya serta memberikan tanggapan.

Selama proses pembelajaran berlangsung, observator (guru mata pelajaran matematika kelas VII) mengobservasi jalannya pembelajaran dengan menggunakan lembar observasi untuk guru (peneliti) dan siswa.

Hal-hal yang diobservasi pada pelaksanaan tindakan siklus I adalah cara guru menyajikan materi pelajaran apakah sudah sesuai dengan skenario pembelajaran yang telah dibuat atau belum. Selain itu juga dilihat aktivitas siswa dalam mengikuti pelajaran.

Hasil observasi terhadap guru menunjukkan hal-hal sebagai berikut: Guru memberi motivasi dan memberi apersepsi; Guru tidak menjelaskan tujuan pembelajaran; Guru mengorganisasi siswa dalam 5 kelompok belajar dan setiap kelompok terdiri dari 5 orang; Guru memberikan bimbingan kepada setiap kelompok; Guru menyiapkan LKS sebagai alat bantu dalam pembelajaran; Guru belum mampu mengelola waktu dengan baik, akibatnya ada tahapantahapan dalam skenario pembelajaran yang tidak terlaksana karena kehabisan waktu

Hasil observasi terhadap siswa menunjukkan hal-hal sebagai berikut: Pada pertemuan pertama siswa terlihat masih kaku jika berada dalam kelompoknya; Sebagian kecil siswa masih kurang aktif dalam mengerjakan soal-soal dalam LKS yang telah diberikan; Sebagian siswa masih ragu mengemukakan pendapat; Hanya beberapa siswa yang mampu mempresentasikan hasil kerja kelompoknya dan ada siswa yang merasa gugup ketika nomornya terpanggil untuk mempresentasikan hasil kerja kelompoknya.

Setelah pelaksanaan tindakan siklus I selama 2 kali pertemuan, diadakan evaluasi/tes hasil belajar. Hasil tes siklus I menunjukkan bahwa tidak terjadi peningkatan jika dibandingkan dengan hasil tes awal yaitu semua siswa memperoleh nilai $<75$, dengan nilai ratarata siswa yaitu 40,14. Hasil tes siklus I tidak menunjukkan peningkatan dan belum mencapai indikator keberhasilan maka penelitian dilanjutkan pada siklus II.

Pada tahap prefleksi secara kolaboratif, peneliti dan guru mendiskusikan kelemahankelemahan yang terdapat pada pelaksanaan 
tindakan siklus I kemudian akan diperbaiki pada tindakan siklus II.

Model pembelajaran kooperatif tipe NHT ini memang masih baru bagi siswa, sehingga siswa belum memahami betul langkahlangkah pelaksanaan model pembelajaran kooperatif tipe NHT. Masih ada siswa yang belum bisa bekerja sama dan aktif berdiskusi dengan teman kelompoknya, karena siswa masih terpengaruh dengan model pembelajaran sebelumnya. Selama ini siswa terbiasa bekerja secara individual dan menonjolkan kemampuan masing-masing tanpa memperdulikan siswa lainnya yang belum mengerti.

Pada kegiatan pendahuluan setelah membuka pelajaran guru tidak menyampaikan indikator pencapaian hasil belajar dan tujuan pembelajaran. Semestinya kedua hal ini sangat penting untuk mengfokuskan kegiatan belajar dan membangkitkan minat siswa agar tertarik dan tekun mengikuti pelajaran, akibatnya banyak siswa yang tidak serius mengikuti pelajaran di tengah-tengah proses diskusi kelompok. Begitu juga pemantauan kegiatan kelompok masih kurang efektif, sehingga kelompok yang lebih membutuhkan bimbingan guru tidak diperhatikan. Bantuan yang diberikan oleh guru pada kelompok yang mengalami kesulitan langsung pada jawaban, tanpa membimbing terlebih dahulu. Selain itu guru tidak memperhitungkan waktu yang digunakan pada waktu penyampaian materi pelajaran, sehingga tahap-tahap pembelajaran dengan menggunakan model kooperatif tipe NHT tidak terlaksana dengan tuntas. Begitu juga dengan PR, guru tidak mendiskusikan terlebih dahulu dengan siswa nomor yang dianggap sulit, tetapi buku mereka diminta untuk dikumpulkan dan kemudian diperiksa oleh guru.

Setelah melihat hasil evaluasi tes tindakan siklus I dan pelaksanaan skenario pembelajaran ternyata belum memenuhi indikator kinerja, maka penelitian dilanjutkan ke siklus II.

Berdasarkan hasil observasi dan evaluasi, pelaksanaan tindakan siklus I belum mencapai indikator keberhasilan yang telah ditetapkan, sehingga peneliti bersama guru merencanakan tindakan siklus II. Kelemahankelemahan dan kekurangan-kekurangan yang ada pada siklus I akan diperbaiki pada siklus II.

Hal-hal yang perlu dilakukan dalam memperbaiki kelemahan dan kekurangan pada siklus I untuk diperbaiki pada siklus II adalah :
Guru harus memotivasi siswa agar siswa bersemangat dalam belajar serta guru harus memberikan apersepsi; Guru harus bersikap tegas dengan menegur/memberi sanksi kepada siswa yang tidak memperhatikan penjelasan guru; Guru harus selalu memberikan kesempatan yang seluas-luasnya kepada siswa untuk menanyakan hal-hal yang tidak dimengerti; Guru harus mampu mengelola waktu dengan efisien agar semua tahapan kegiatan dalam skenario pembelajaran dapat terlaksana.

Selain hal-hal yang merupakan rencana perbaikan untuk tindakan siklus I, peneliti harus mempersiapkan juga skenario pembelajaran, lembar observasi untuk guru dan siswa, alat evaluasi dan jurnal refleksi diri untuk tindakan siklus II.

Pada pelaksanaan tindakan siklus II ini, guru kembali berusaha melaksanakan pembelajaran agar sesuai dengan skenario pembelajaran tindakan siklus II. Kegiatan pembelajaran diawali dengan guru menyampaikan tujuan pembelajaran yang hendak dicapai dengan maksud agar siswa memiliki gambaran jelas tentang pengetahuan yang akan diperoleh setelah proses pembelajaran berlansung. Guru juga melakukan tindakan perbaikan sebagaimana yang telah direncanakan pada tahap perancanaan meskipun belum maksimal. Materi yang diajarkan masih dalam materi bentuk aljabar.

Selama proses pembelajaran berlansung, observator mengobservasi pelaksanaan pembelajaran dengan menggunakan lembar observasi untuk guru dan siswa.

Secara umum pada pelaksanaan tindakan siklus II ini telah ada peningkatan dibandingkan dengan siklus I. Hal ini terlihat pada hasil observasi guru dan siswa.

Hasil observasi terhadap guru menunjukan bahwa: Guru selalu menjelaskan tujuan pembelajaran dan namun lupa untuk memotivasi siswa; Guru sudah bersikap tegas dengan menegur/memberi sanksi kepada siswa yang tidak memperhatikan penjelasan guru;

Guru memberikan bimbingan kepada kelompok atau siswa yang mengalami kesulitan dalam menyelesaikan soal-soal dalam LKS dan memberikan penghargaan kepada kelompok/siswa yang menjawab dengan benar; Guru sudah dapat melaksanakan hampir semua tahapan kegiatan dalam skenario pembelajaran pada siklus II. 
Hasil observasi terhadap siswa menunjukan bahwa: Siswa memperhatikan dengan baik penjelasan guru; Sebagian siswa sudah berani menanyakan hal-hal yang kurang dimengerti yang ada kaitannya dengan materi yang diajarkan; Sebagian besar siswa sudah mampu mempresentasikan hasil kerja kelompoknya.

Setelah 2 kali pertemuan yang membahas materi bentuk aljabar, kembali diadakan evaluasi untuk mengetahui peningkatan hasil belajar matematika siswa.

Hasil tes siklus II menunjukkan peningkatan hasil belajar matematika siswa dibandingkan dengan siklus I yaitu dari $0 \%$ (tidak ada satupun) siswa yang telah memperoleh nilai $\geq 75$ pada siklus I, meningkat menjadi $44 \%$ (11 orang) siswa telah memperoleh nilai $\geq 75$ pada siklus II. Dari hasil tes siklus II, walaupun menunjukkan peningkatan tetapi karena belum mencapai indikator keberhasilan maka penelitian dilanjutkan pada siklus III.

Berdasarkan hasil observasi dan evaluasi pelaksanaan tindakan siklus II, hal yang masih perlu diperhatikan adalah bimbingan terhadap siswa yang mengalami kesulitan dalam mengerjakan latihan perlu ditingkatkan. Kelemahan-kelemahan dan kekurangankekurangan yang terjadi pada tindakan siklus II akan diperbaiki pada pelaksanaan tindakan siklus III.

Berdasarkan hasil observasi, evaluasi dan refleksi diri pada tindakan siklus II, maka peneliti bersama dengan guru merencanakan tindakan siklus III agar kekurangan-kekurangan pada tindakan siklus II dapat diperbaiki.

Adapun hal-hal yang perlu dilakukan dalam rangka memperbaiki tindakan siklus II adalah guru harus selalu membimbing siswa dalam mengerjakan soal-soal LKS yang telah diberikan. Selain itu, pada tahap perencanaan ini peneliti tetap membuat skenario pembelajaran, lembar observasi terhadap guru dan siswa, alat evaluasi dan jurnal refleksi diri untuk tindakan siklus III.

Pelaksanaan pembelajaran dengan model pembelajaran kooperatif tipe NHT kembali dilakukan dengan mengikuti skenario pembelajaran yang telah dibuat untuk pelaksanaan tindakan siklus III.

Kegiatan yang dilakukan setiap pertemuan pada siklus III adalah diawali dengan menyampaikan tujuan pembelajaran yang akan dicapai pada akhir proses belajar mengajar dan memberikan motivasi kepada siswa agar bersemangat dalam belajar. Selama proses pembelajaran berlangsung guru tetap memantau dan memberikan bimbingan kepada setiap kelompok atau siswa yang mengalami kesulitan. Selama proses belajar mengajar berlangsung observator mengobservasi jalannya pembelajaran dengan menggunakan lembar observasi untuk guru dan siswa.

Peneliti dan observator kembali melaksanakan observasi terhadap pelaksanaan tindakan siklus III dan hasil observasi terhadap guru menunjukkan bahwa guru telah mampu melaksanakan skenario pembelajaran dengan baik. Hasil observasi terhadap siswa menunjukkan hal-hal berikut: Semua siswa sudah memperhatikan penjelasan guru; Siswa sudah mampu mempresentasikan hasil kerja kelompoknya; Siswa sudah mampu mengemukakan pendapat; Siswa masih belum mampu membuat kesimpulan.

Secara umum pelaksanaan tindakan sudah sesuai dengan skenario pembelajaran yang telah dibuat. Semua tahapan kegiatan dalam skenario pembelajaran telah dilaksanakan dengan sempurna oleh guru. Hanya masih ada sedikit kelemahan-kelemahan pada pihak siswa yaitu ada beberapa siswa yang belum mampu mengemukakan pendapat dan siswa juga belum mampu membuat kesimpulan di akhir pembelajaran.

Setelah 2 kali pertemuan, maka kembali diadakan tes tindakan siklus III untuk mengetahui peningkatan hasil belajar matematika siswa. Hasil tes menunjukkan adanya peningkatan dari siklus sebelumnya yaitu dari $44 \%$ (11 orang) siswa telah memperoleh nilai $\geq 75$ pada siklus II, meningkat menjadi $80 \% \quad(20$ orang $)$ siswa telah memperoleh nilai $\geq 75$ pada siklus III.

Dari hasil tes siklus III menunjukkan adanya peningkatan dan telah mencapai indikator keberhasilan yang telah ditetapkan, maka pelaksanaan tindakan dihentikan hanya sampai pada siklus III).

Kegiatan refleksi yang dilakukan pada tindakan siklus III menunjukkan hasil yang cukup menggembirakan baik bagi guru mata pelajaran maupun bagi peneliti. Hasil observasi yang dilakukan oleh peneliti menunjukkan bahwa pembelajaran dengan menggunakan model pembelajaran kooperatif tipe NHT sudah mendapatkan hasil yang lebih baik, walaupun 
masih ada beberapa siswa yang belum dapat menyampaikan pendapat tetapi siswa tersebut aktif melibatkan diri dalam melaksanakan tugas kelompok.

Jika dilihat dari hasil tes pada evaluasi pelaksanaan tindakan siklus III, yaitu telah mencapai $80 \%$ (20 orang) siswa yag telah memperoleh nilai $\geq 75$ atau dengan kata lain telah mencapai indikator keberhasilan, maka penelitian ini telah berhasil dilaksanakan sesuai rencana pelaksanaan penelitian dengan tiga siklus tindakan.

Tabel 1

Data nilai hasil belajar matematika siswa dari siklus I hingga siklus III

\begin{tabular}{|c|l|c|c|c|}
\hline No & \multicolumn{1}{|c|}{ Nama } & Siklus I & Siklus II & Siklus III \\
\hline 1. & Alya Inso & 60,6 & 94 & 88 \\
\hline 2. & Abdul Malik Mini & 36,36 & 76 & 84 \\
\hline 3. & Abdi Panata & 1,5 & 0 & 76 \\
\hline 4. & Ahmadi & 60,6 & 0 & 76 \\
\hline 5. & Alan & 40,9 & 82 & 80 \\
\hline 6. & Farel Farezi & 39,39 & 72 & 76 \\
\hline 7. & Fina & 57,57 & 78 & 62 \\
\hline 8. & Harlina & 51,51 & 76 & 84 \\
\hline 9. & Hadija & 46,96 & 76 & 84 \\
\hline 10. & Harmawati & 50 & 72 & 92 \\
\hline 11. & Imelda & 62,12 & 76 & 84 \\
\hline 12. & Kadar & 1,5 & 0 & 26 \\
\hline 13. & Nani & 56,06 & 68 & 88 \\
\hline 14. & Nur Yeni & 42,42 & 74 & 92 \\
\hline 15. & Puput Saputri Hasanudin & 54,54 & 72 & 96 \\
\hline 16. & Rika & 65,15 & 94 & 96 \\
\hline 17. & Rahmat Tian Saputra & 21,21 & 72 & 72 \\
\hline 18. & Rani Rubianti & 54,54 & 68 & 100 \\
\hline 19. & Karlina & 0 & 74 & 76 \\
\hline 20. & Sumiana & 50 & 76 & 80 \\
\hline 21. & Saiful Akmar & 51,51 & 86 & 80 \\
\hline 22. & Suparman & 31,81 & 74 & 0 \\
\hline 23. & Yuyun & 0 & 24 & 80 \\
\hline 24. & Waode Wantri & 34,84 & 74 & 76 \\
\hline 25. & Yunita & 33,33 & 76 & 96 \\
\hline & & 1004,42 & 1634 & 1944 \\
\hline & & 40,14 & 65,36 & 77,76 \\
\hline & & & \\
\hline
\end{tabular}

Peningkatan dapat dilihat dari banyaknya siswa yang tuntas pada hasil evaluasi dari siklus I sampai siklus III, secara berturutturut yaitu: $0 \%, 44 \%$, dan $80 \%$. Adapun persentase peningkatan skor rata-rata hasil belajar siswa dari siklus I ke siklus II yaitu
25,22, sedangkan siklus II ke siklus III yaitu sebesar 12,4\%. Berikutnya, rekapitulasi ketercapaian proses pelaksanaan tindakan dan rekapitulasi hasil belajar matematika siswa tiap siklus tersaji dalam diagram berikut: 


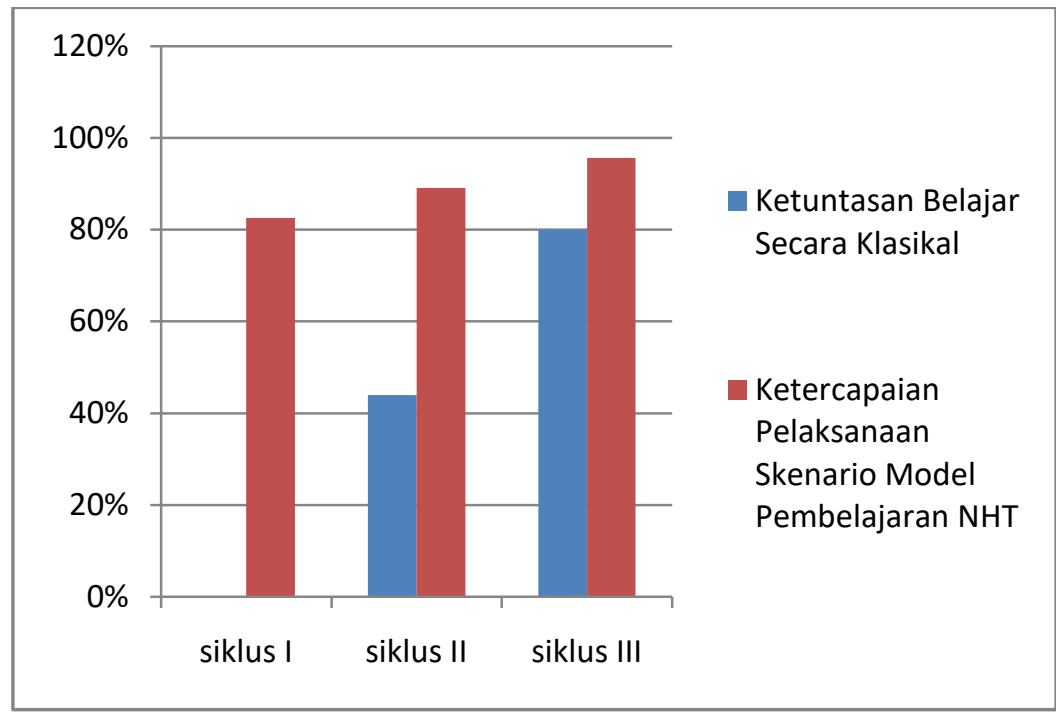

Diagram 1. Grafik Hasil Belajar Siswa pada Siklus I, Siklus II, dan Siklus III

Diagram 1. menunjukkan bahwa persentase ketuntasan hasil belajar siswa mengalami peningkatan dari siklus I sampai siklus III yakni pada siklus I persentase ketuntasan $0 \%$ yang mencapai KKM dengan persentase ketidaktuntasan $100 \%$, pada siklus II mengalami peningkatan dengan persentase ketuntasan $40 \%$ yang mencapai KKM dengan persentase ketidaktuntasan $60 \%$, sedangkan pada siklus III juga mengalami peningkatan dengan persentase ketuntasan $80 \%$ telah mencapai standar KKM dengan persentase ketidaktuntasannya $20 \%$.

\section{Pembahasan}

Menurut Kardiawarman (Paizaluddin dan Ermalinda, 2016: 6) mendefenisikan PTK sebagai suatu bentuk penelitian yang dilakukan pada sebuah kelas untuk mengetahui akibat tindakan yang diterapkan pada suatu subyek penelitian di kelas tersebut. Penelitian Tindakan Kelas (PTK) merupakan suatu penelitian yang dilakukan oleh guru/calon guru dalam kelasnya melalui refleksi diri yang bertujuan untuk memperbaiki proses pembelajaran sehingga hasil belajar siswa mengalami peningkatan. Pelaksanaan penelitian ini terdiri dari enam pertemuan yang dibagi menjadi tiga siklus.

Penelitian ini berakhir setelah pelaksanaan siklus III dan telah mencapai indikator kinerja yang telah ditetapkan. Pada siklus I, perolehan nilai siswa berdasarkan ketuntasan belajar yaitu 0\% (tidak ada siswa yang memenuhi kriteria ketuntasan minimal).
Seluruh siswa memperoleh nilai $<75$, berarti nilai evaluasi hasil tes siklus I tidak mengalami peningkatan dari hasil tes awal. Berdasarkan hasil observasi pada siklus I, persentase ketercapaian pelaksanaan skenario pembelajaran yaitu 82,60\% (Lampiran 9 halaman 156). Guru dan siswa telah melakukan kegiatan pembelajaran yang sesuai dengan model pembelajaran kooperatif tipe NHT, namun masih terdapat kekurangan-kekurangan dimana kekurangan itu ada yang berasal dari guru dan ada juga yang berasal dari siswa. Diantaranya ada sebagian siswa yang tidak memperhatikan penjelasan guru pada saat menyampaikan materi, dan kekurangan yang berasal dari guru adalah belum terlaksananya semua komponen dalam skenario pembelajaran. Hal itu dikarenakan guru belum dapat mengatur waktu sebaik mungkin, guru terlalu banyak memberikan waktu pada siswa untuk bekerja menyelesaikan soal-soal yang diberikan, dan guru (peneliti) merasa canggung dalam mengajar karena kehadiran observator (guru mata pelajaran matematika kelas VII). Melihat kekurangan yang masih ada serta hasil belajar matematika siswa terhadap materi bentuk aljabar pada tindakan siklus I belum memenuhi indikator keberhasilan yang telah ditetapkan, maka penelitian dilanjutkan pada tindakan siklus II. Hal-hal yang harus diperbaiki pada tindakan siklus II adalah guru harus bersikap tegas dengan menegur/memberi sanksi kepada siswa yang tidak memperhatikan penjelasan guru dan yang tidak mau bekerja sama dengan teman kelompoknya. Guru juga harus mampu 
mengelola waktu dengan efisien agar semua tahapan kegiatan dalam skenario pembelajaran dapat terlaksana.

Pada tindakan siklus II, model pembelajaran kooperatif tipe NHT kembali dilaksanakan. Berdasarkan hasil observasi pada tindakan siklus II, kegiatan guru dalam melaksanakan proses pembelajaran telah meningkat. Jika dipersentasekan, ketercapaian pelaksanaan skenario pembelajaran yaitu $89,12 \%$. Kekurangan-kekurangan yang terjadi pada siklus I sudah dapat diperbaiki sedikit demi sedikit. Siswa sudah lebih memperhatikan penjelasan guru walaupun hanya beberapa siswa mampu dan mau mengajukan pertanyaan jika mendapat masalah dalam menyelesaikan soalsoal LKS yang diberikan. Berdasarkan hasil evaluasi yang dilakukan pada siklus II, siswa yang tuntas atau memperoleh nilai $\geq 75$ (telah memenuhi KKM) sebanyak 11 orang atau $44 \%$, sedangkan 14 orang atau $56 \%$ siswa masih belum tuntas karena memperoleh nilai $<75$ (belum memenuhi KKM), dengan nilai rata-rata siswa yaitu 65,36. Ini berarti mengalami peningkatan dibanding hasil evaluasi pada siklus I.

Ketercapaian pelaksanaan skenario pembelajaran pada siklus II ini telah memenuhi indikator keberhasilan yang telah ditetapkan. Namun, karena melihat hasil evaluasi siklus II belum mencapai indikator keberhasilan yang telah ditetapkan maka penelitian dilanjutkan kembali pada siklus berikutnya. Hal-hal yang harus diperbaiki pada siklus III adalah guru harus selalu membimbing siswa dalam mengerjakan soal-soal yang diberikan.

Setelah siklus III, nilai siswa menunjukkan lagi peningkatan menjadi $80 \%$ siswa telah tuntas atau memperoleh nilai $\geq 75$ (telah memenuhi KKM) dan secara rata-rata juga meningkat menjadi 77,76. Sedangkan persentase ketercapaian pelaksanaan skenario pembelajaran pada siklus III ini yaitu 95, 65\%. Hal ini berarti telah mencapai indikator keberhasilan yang telah ditetapkan. Oleh karena indikator keberhasilan dalam penelitian telah tercapai, ini berarti hipotesis tindakan telah tercapai yaitu dengan menggunakan model pembelajaran kooperatif tipe NHT hasil belajar matematika siswa kelas VIIA SMP Negeri 3 Mawasangka pada materi bentuk aljabar dapat ditingkatkan.

\section{Simpulan dan Saran}

\section{Simpulan}

Berdasarkan rumusan masalah dan hasil analisis data melalui penggunaan model pembelajaran kooperatif tipe NHT pada materi bentuk aljabar di kelas VII $_{\mathrm{A}}$ SMP Negeri 3 Mawasangka dapat ditarik kesimpulan sebagai berikut:

1. Aktivitas mengajar guru dari siklus I sampai dengan siklus III mengalami peningkatan yang dapat dilihat dari hasil observasi kegiatan guru. Ketercapaian pelaksanaan skenario model pembelajaran kooperatif Tipe NHT dari siklus I hingga siklus III secara berturut-turut yaitu $82,60 \%, 89,12 \%$, dan $95,65 \%$.

2. Gambaran aktivitas belajar siswa dari siklus I sampai dengan siklus II mengalami peningkatan.

3. Hasil belajar matematika siswa kelas $\mathrm{VII}_{\mathrm{A}}$ SMP Negeri 3 Mawasangka pada materi bentuk aljabar dapat ditingkatkan dengan menggunakan model pembelajaran kooperatif tipe Numbered Heads Together. Peningkatan ini dilihat dari hasil tes awal dan tes tindakan siklus II yaitu dari 0\% atau tidak ada siswa yang tuntas (seluruh siswa belum memenuhi KKM) menjadi $44 \%$ siswa yang tuntas ( telah memenuhi KKM), dan dari siklus II ke siklus III yaitu dari $44 \%$ siswa yang tuntas ( telah memenuhi KKM) menjadi $80 \%$ siswa yang tuntas (telah memenuhi KKM). Dari segi proses, ketercapaian pelaksanaan skenario model pembelajaran kooperatif Tipe Numbered Heads Together mengalami peningkatan dari siklus I hingga siklus III secara berturut-turut yaitu $82,60 \%, 89,12 \%$, dan $95,65 \%$.

\section{Saran}

Berdasarkan kesimpulan yang telah diperoleh dalam penelitian ini, maka peneliti memberikan saran sebagai berikut:

1. Bagi sekolah, khususnya SMP Negeri 3 Mawasangka agar dapat menggunakan model pembelajaran kooperatif tipe NHT dalam pembelajaran khususnya pada mata pelajaran matematika untuk mengatasi siswa yang kurang aktif dan untuk meningkatkan hasil belajar matematika siswa. 
2. Bagi guru mata pelajaran matematika diharapkan dapat mengetahui, memahami dan menerapkan model pembelajaran kooperatif tipe NHT dalam pembelajaran sebagai alternatif tindakan yang efektif dalam upaya meningkatkan hasil belajar matematika siswa.

3. Untuk peneliti-peneliti lain diharapkan untuk memperhatikan dan lebih memahami model pembelajaran kooperatif tipe NHT, sehingga pada penelitian selanjutnya tidak lagi menghadapi kendala dalam proses pembelajaran, khususnya upaya-upaya untuk mengaktifkan siswa dan penggunaan media pembelajaran yang sesuai dengan materi pelajaran.

\section{Daftar Pustaka}

Aqib, Zainal. (2015). Model-Model, Media, dan Strategi Pembelajaran Kontekstual (Inovatif). Bandung: Penerbit Yrama Widya.

As'ari, A. R., Tohir, M., Valentino, E., Imron, Z., dan Ibnu Taufiq. (2016). Buku Guru Matematika SMP/MTs Kelas VII Kurikulum 13 Edisi Revisi 2016. Jakarta: Kemdikbud.

Fitri, R., Helma, dan Hendra Syarifuddin. (2014). Penerapan Strategi The Firing Line Pada Pembelajaran Matematika Siswa Kelas XI IPS SMA Negeri 1 Batipuh. Jurnal Pendidikan Matematika. 3 (1).

Ibrahim, M., Rachmadiarti, F., Ismono, dan Muhammad Nur. (2000). Pembelajaran Kooperatif. Surabaya: UNESA - University Press.

Ichsan, Muhammad. (2016). Psikologi Pendidikan Dan Ilmu Mengajar. Jurnal Edukasi. 2 (1). ISSN: 2460-4917. EISSN: 2460 - 5794.

Jihad, Asep dan Abdul Haris. (2008). Evaluasi Pembelajaran. Jakarta: Multi Presindo.

Paizaluddin dan Ermalinda. (2012). Penelitian Tindakan Kelas (Classroom Action Research) Panduan Teoritis Dan Praktis. Palembang: Alfabeta.
Suprijono, A. (2009). Cooperative Learning Teori dan Aplikasi PAIKEM. Yogyakarta: Pustaka Pelajar.

Sutrisno, V. L. P., dan Siswanto, B. T. (2016). "Faktor-Faktor Yang Mempengaruhi Hasil Belajar Siswa Pada Pembelajaran Praktik Kelistrikan Otomotif SMK Di Kota Yogyakarta". Jurnal Pendidikan Vokasi. 06 (01).

Ubaidah, Nila. (2016). Pemanfaatan CD Pembelajaran Untuk Meningkatkan Kemampuan Komunikasi Matematis Siswa Melalui Pembelajaran Make A Match. Jurnal Pendidikan Matematika FKIP Unissula. 4 (1). ISSN: 2338 5988.

Viyanita, E. L. (2013). Peningkatan Hasil Belajar Matematika Siswa Kelas XI IPA SMA Negeri 2 Konawe Selatan Pada Materi Pokok Statistik Dengan Menggunakan Model Pembelajaran Kooperatif Tipe NHT. Kendari: Skripsi Universitas Halu Oleo.

Wardani, C. K. (2016). Implementasi Model Pembelajaran Kooperatif Tipe Numbered Heads Together (NHT) Untuk Meningkatkan Prestasi Belajar Kompetensi Dasar Jurnal Khusus Siswa Kelas X Akuntansi 2 SMK Koperasi Yogyakarta Tahun Ajaran 2015/2016. Yogyakarta: Skripsi Universitas Yogyakarta.

Yasin, Salehuddin. (2012). Metode Belajar Dan Pembelajaran Efektif. Jurnal Adabiyah. XII (I). ISSN: 1421 6141 